\title{
ethic@

\section{DIVERSIDADE RELIGIOSA E DEMOCRACIA: DA FILOSOFIA DA RELIGIÃO À FILOSOFIA POLÍTICA}

\author{
RELIGIOUS DIVERSITY AND DEMOCRACY: FROM \\ PHILOSOPHY OF RELIGION TO POLITICAL PHILOSOPHY
}

\author{
MARCIANO ADILIO SPICA ${ }^{1}$
}

(UNICENTRO/Brasil)

\begin{abstract}
RESUMO
Atualmente, vivemos em sociedades pluralistas e uma das questões que surge é o de como conciliar democracia e diversidade religiosa, ou seja, o de como definir qual o papel das diferentes religiões na constituição e manutenção de um Estado democrático e como o Estado democrático pode ou deve agir em relação a resolução de conflitos que podem advir da diversidade. Tentar dar uma contribuição a um modo de pensar apropriadamente esta questão é o objetivo deste trabalho. Para fazer isso, pretendo, num primeiro momento mostrar três respostas possíveis que a filosofia da religião dá à diversidade religiosa e tomar partido de uma das respostas, a saber, o pluralismo. Defenderei que aceitar o pluralismo de crenças e tomálo como legítimo é necessário e benéfico para as sociedades democráticas. Em um segundo momento, proporei uma tese segundo a qual, as religiões têm papel na esfera pública como participante ativa nos debates das questões democráticas, porém, uma religião particular não pode pretender o papel de definidora das questões democráticas. Ao final, apresentarei alguns desafios que a diversidade religiosa traz para o conceito de Estado secular.
\end{abstract}

Palavras-chave: Religiões; Diversidade; Democracia; Pluralismo.

\begin{abstract}
We live currently in pluralistic societies and one of the main questions that arises is how to reconcile democracy and religious diversity. The problem is how to define the role of different religions in the Constitution and maintaining a democratic state and how the democratic state can or should act in relation to the resolution of conflicts that emerge from diversity. The intent of this essay is to contribute to think appropriately these questions. To achieve this aim, I intend, firstly, to discuss three possible answers that philosophy of religion gives to religious diversity and to show the advantages of one of the answers, namely pluralism. Thus, I will argue that it is necessary and beneficial for democratic societies accepting pluralism of beliefs and taking it as legitimate. Secondly, I will propose the thesis that religions have a role in the public sphere as an active participant in the debates of democratic issues, but one religion cannot claim to play the role of defining democratic issues. In the end, I will present some challenges that religious diversity presents to the concept of secular state.
\end{abstract}

Keywords: Religions; Diversity; Democracy; Pluralism.

\section{Três respostas filosóficas à diversidade religiosa e as vantagens do pluralismo}

Atualmente, as sociedades ocidentais caracterizam-se por uma grande pluralidade interna e pelo reconhecimento de uma pluralidade externa. Ao mesmo tempo 
que convivem internamente com diferentes grupos religiosos, também há consciência de que existe um grande número de manifestações religiosas que não são conhecidas profundamente, mas que são seguidas por milhares e até milhões de pessoas. Deste modo, o sujeito contemporâneo é alguém que convive, por vontade própria ou força das circunstâncias, em uma complexa pluralidade de crenças religiosas.

Esse complexo cenário religioso é um terreno fértil para a filosofia da religião, pois ele gera, entre muitas outras, questões como: há algum privilégio epistêmico que torna um sistema de crenças $A$ melhor ou mais aceitável que um sistema de crenças $B$ ? Todas as teses de todas as religiões são legítimas e nenhuma delas é detentora da verdade? A diversidade de crenças deve me fazer desconfiar de meu sistema de crenças particular? Há um critério último a partir do qual posso decidir, de forma segura, que um sistema de crenças é correto e outro não? É possível uma disputa legítima entre crenças particulares?

A Filosofia da Religião tem tentado dar respostas a essas e outras questões geradas pela diversidade. Suas respostas podem ser divididas em três grandes grupos, a saber, exclusivismo, inclusivismo e pluralismo ${ }^{2}$. O exclusivismo é a teoria que defende que um determinado sistema de crenças possui a verdade e é o sistema de crenças correto, enquanto todos os outros estão errados. Neste sentido, o exclusivista é alguém que, mesmo consciente da pluralidade religiosa, continua a tomar como verdadeiras as sentenças de sua religião e, em consequência, entende como falsas as sentenças e visões de mundo de outras religiões ${ }^{3}$. Essa foi, por exemplo, a posição adotada pela Igreja Católica até o Concílio Vaticano II, através da doutrina extra ecclesiam nulla salus e é a posição de respeitados pensadores contemporâneos como Karl Barth (1956) e Alvin Plantinga (2000).

Uma posição próxima ao exclusivismo é o inclusivismo, o qual defende, resumidamente, que mesmo que exista uma única religião verdadeira e, em consequência, uma doutrina que é a verdadeira, os que não concordam com essa doutrina podem ser salvos. São defensores dessa posição, por exemplo, Karl Rahner (2001) e Jacques Maritain (1959). A principal diferença entre o exclusivista e o inclusivista é que o primeiro rechaça a possibilidade de salvação e verdade para quem não acredita em suas crenças, enquanto a segunda abordagem afirma a possibilidade dela. $\mathrm{Na}$ verdade, o inclusivismo é uma forma menos radical de exclusivismo ${ }^{4}$.

Para além das respostas inclusivistas e exclusivistas, uma terceira abordagem, a meu ver mais plausível, é o pluralismo que, resumidamente, pode ser caracterizado como 
a posição diante da pluralidade religiosa que defende não haver problemas lógicos e/ou epistemológicos em se adotar crenças diversas sobre um mesmo assunto. O pluralista é alguém que defende que as diversas manifestações religiosas presentes no mundo são manifestações linguístico/culturais que são legítimas e devem ser respeitadas. Entre os representantes dessa posição estão, por exemplo, John Hick e Victoria Harisson.

Hick justifica a diversidade religiosa tomando como ponto de partida a distinção, emprestada de $\mathrm{Kant}^{5}$, entre a realidade fenomênica e a realidade numênica. Para Kant, a única coisa passível de conhecimento é a realidade fenomênica; a coisa em si ou realidade numênica é algo que não se pode conhecer ou não se tem acesso. Hick aplica essa distinção à questão da pluralidade de crenças religiosas, fazendo uma separação entre o Real (equivalente ao numênico) e as várias formas nas quais o Real é pensado ou experienciado nas diferentes manifestações religiosas (equivalente ao mundo fenomênico). Essa distinção só é possível porque as manifestações religiosas não são meramente projeções humanas, mas envolvem, todas elas, uma resposta a uma realidade transcendente. Todas as grandes religiões do mundo possuem a ideia de transcendência e, mais do que isso, concordam com a impossibilidade de descrever tal realidade em sua totalidade (HICK, 2010, p. 164). A grande variedade de religiões que se encontram no mundo se dá pelo fato dessas serem tentativas de descrições da realidade última, entendida como o Real. O Real é algo que nenhuma religião tem acesso, ou melhor, nenhuma religião pode dizer que tem uma descrição completa do Real, pois ele é transcategorial, no sentido de estar para além das categorias do entendimento humano, e qualquer tentativa de descrevê-lo como ele realmente é sempre falha, pois as formas do entendimento limitam nossa capacidade de conhecê-lo, tornando-o inacessível. Dado que nenhum ser humano pode ter acesso ao Real em si, Hick defende que nem exclusivismo nem inclusivismo fazem sentido e defende que todas as religiões possuem legitimidade em suas afirmações. O que Hick quer dizer é que, dada a distinção de viés kantiano entre Real em si e o real fenomênico, tal acesso ou descrição é impossível a qualquer ser humano. Em suma, todos são ignorantes diante do Real. Diante disso, Hick sustenta que todas as religiões são dignas de crença. Como não se pode ter acesso ao Real, não se pode também descartar qualquer interpretação dele como falsa. Assim, o pluralismo estaria justificado e deve ser respeitado já que as diferenças entre as diversas religiões estariam naturalmente ligadas ao modo de conhecer. 
O grande problema da tese de Hick é sua insistência na ideia de que nenhuma religião é detentora de verdades e nenhuma delas pode se arrogar o direito de ter uma descrição mais ou menos verdadeira do Real - segundo ele, não podemos nem mesmo falar em gradações de confiabilidade das crenças religiosas. Dado isso, a questão que restaria é: qual seria o conteúdo de um possível diálogo inter-religioso e das religiões com o mundo não religioso? Sobre o que exatamente a religião poderia falar? Neste sentido, a tese de Hick sofre resistências de vários autores, os quais o acusam, dentre outras coisas, de tentar modificar o conteúdo das crenças religiosas ou mesmo de uma tentativa de privatização das mesmas, não restando às religiões nenhum papel realmente importante na esfera pública ou, se restar, as mesmas teriam de se modificar completamente (WOLTERSTORFF, 2012; TRIGG, 2014; SPICA, 2018).

Numa tentativa de responder às críticas que a teoria de Hick vem sofrendo, Victoria Harrison tentou esboçar uma nova teoria pluralista baseada nas ideias epistemológicas de Putnam. Tal tese é conhecida como pluralismo internalista e é:

[...] uma adaptação, aos domínios religiosos, do realismo internalista - uma teoria primeiramente defendida por Hilary Putnam. Como o realismo interno putniano, o defensor do pluralismo internalista sustenta que seja qual for o objeto que pode ser dito existir, ele é dependente de um esquema conceitual e seja qual for o significado de um objeto existir, ele é igualmente dependente de um esquema conceitual. (HARRISON, 2008, p. 98).

Harrison defende que, aplicado à religião, o realismo interno de Putnam leva ao pluralismo interno, que tem como tese central a ideia de que as realidades e declarações religiosas podem somente ser entendidas e discutidas corretamente dentro de um esquema conceitual particular e não faz sentido falar de um "Real" que exista fora de um esquema conceitual, ou seja, não há um centro ao redor do qual as religiões particulares giram e que esteja fora de seu esquema conceitual. Para Harrison, os esquemas conceituais determinam o que conta ou não conta como verdadeiro, o que conta ou não conta como real. Dessa forma, o problema da disputa entre as diferentes religiões seria dissolvido já que não pode haver uma "legítima disputa entre diferentes sistemas de crenças sobre a objetividade de suas respectivas reinvindicações, a menos que eles entrem genuinamente no sistema de crenças um do outro" (HARRISON, 2006, p. 293). Assim, segundo Harrison, teríamos uma radical teoria do pluralismo.

Na realidade, o que a filósofa defende é que as realidades e declarações religiosas podem somente ser entendidas e discutidas corretamente dentro de um esquema 
conceitual particular, não fazendo sentido falar de um "Real" que exista fora deste esquema. Essa seria uma verdadeira revolução no modo como entendemos a diversidade e uma defesa do pluralismo de crenças, para ser consistente, deveria reconhecer que uma discussão significativa das pretensas realidades e verdades religiosas só é possível se forem entendidas dentro de seus respectivos esquemas conceituais ou 'instâncias de fé'.

Harrison tem demonstrado que sua tese é mais abrangente e resolve alguns dos problemas da tese de Hick (HARRISON, 2006, pp. 295-298), principalmente a ideia de que as religiões não trabalhariam com verdades e o fato de que ela incluiria em sua definição de religião, muito mais religiões do que Hick e assumiria que há diferenças genuínas entre as diferentes religiões. Mesmo assim, entendo que a teoria pluralista de Harrison tem problemas se aplicada à questão do papel da religiosidade na esfera pública. Pois, mesmo que ela assuma que há diferenças legítimas entre as diferentes religiões, fica a questão de como acessar essas diferenças, já que parece que para tal seria necessária uma espécie de conversão de um esquema conceitual religioso a outro esquema. Harrison deixa muito claro que numa discussão entre dois sujeitos pertencentes a dois sistemas de crenças diferentes, ambos podem estar certos porque a diferença entre eles pode ser uma diferença totalmente dependente de um esquema conceitual (HARRISON, 2008, p. 103). Se for assim, a pergunta que fica é: um diálogo entre os dois seria um diálogo entre dois surdos? Parece que sim, pois nenhum estaria realmente ouvindo o que o outro está a dizer. Cada um está a falar em seu mundo e para seu mundo ${ }^{6}$. Como conciliar isso com a necessidade de um verdadeiro diálogo inter-religioso e das religiões com os não-crentes e vice-versa em um Estado democrático?

Uma saída às questões colocadas às teses pluralistas, a meu ver, seria elaborar uma teoria que, ao mesmo tempo, respeite a diversidade e permita o diálogo, sem a imposição de uma perspectiva sobre a outra. Um ponto de acesso poderia ser o entendimento de diferentes sistemas de crenças nem como sistemas completamente fechados, nem como diferentes sistemas que possuem uma essência comum, mas como sistemas independentes que possuem certas semelhanças entre uns e outros e que, portanto, podem discutir questões pontuais. A meu ver, é plausível defender que mesmo que sistemas de crenças se desenvolvam em contextos isolados, isso não quer dizer que esse sistema de crenças isolado não seja passível de ser compreendido. Para ficar mais claro: um sistema de crenças de um determinado grupo não é um sistema de crença privado, compreensível apenas a quem participa daquele grupo. Ao serem expressas, as 
crenças desse sistema tornam-se públicas, acessíveis, com os cuidados necessários, a todo ser humano que estiver disposto a compreendê-las. É claro que podemos cometer falhas parciais no entendimento de outro sistema, mas isso não quer dizer que somos incapazes de compreender sistemas alternativos. Na vida prática, na linguagem ordinária e porque não dizer na religião ordinária, há trocas de conhecimentos e práticas. Os diferentes sistemas de crenças não estão completamente desligados e isolados uns dos outros, não há um gap instransponível entre eles. ${ }^{7}$

Não tenho tempo aqui de desenvolver completamente essa ideia, mas, nas próximas seções, ficará claro o fato de que uma teoria pluralista não precisa se comprometer nem com uma ideia forte de que religiões não trabalham com questões de verdade (privatizar a religião), nem tomar os sistemas religiosos como totalmente distantes um do outro, evitando assim o diálogo inter-religioso e das religiões com os nãoreligiosos, diálogo este crucial para a sobrevivência da democracia. Apesar de ter clareza de que as teorias pluralistas enfrentam, elas mesmas, alguns problemas de justificação, entendo que elas respondem melhor aos desafios de uma sociedade plural e, por isso, antes de ir para a próxima seção, cabe algumas notas sobre as vantagens, para a democracia, de uma perspectiva pluralista em comparação com as perspectivas exclusivistas e inclusivistas.

A meu ver, entre as vantagens de uma perspectiva pluralista está o fato de que as mesmas prezam pela afirmação da diversidade e pretendem mostrar que é possível a convivência de diferentes sistemas de crenças, mesmo que haja discordâncias entre os mesmos, o que não parece acontecer nas teses exclusivistas e inclusivistas. Na primeira, parece como se a diversidade religiosa não afetasse a vida dos sujeitos, é como se o dado empírico da diversidade não fosse suficientemente forte para influenciar, em algum sentido, um sistema de crenças em particular. Além disso, o exclusivismo parece sofrer, em termos políticos, do mal do absolutismo já que a ideia fundamental é que um determinado sistema de crenças possui a verdade das questões religiosas e, consequentemente, todos os outros estão errados. Esta ideia pode levar ao fechamento das portas de um possível diálogo inter-religioso e acaba gerando intolerância, já que os que estão errados precisam ou serem convertidos, aceitar a verdade que meu sistema apresenta, ou serão deixados de lado ou até mesmo perseguidos. Em adição, o exclusivismo parece não se sustentar empiricamente, pois como bem expõe Trigg, ao dizer que sua religião ou sistema de crenças está correto e possui a verdade, o exclusivista 
[...]desconsidera a possibilidade de que outras religiões podem reconhecer alguma verdade, [e] todos conhecemos que muitas religiões coincidem em suas asserções. Cristãos, Judeus e Muçulmanos todos concordam que há um Deus, apesar de que pode haver argumentos sobre se eles estão adorando o mesmo Deus (TRIGG, 2014, p. 48).

O que Trigg ressalta é que, ao dizer que um sistema específico é o correto e detentor da verdade, deixa-se de lado o fato de que outros sistemas podem possuir verdades semelhantes ou até compartilhar verdades idênticas e, portanto, não pode ser considerado totalmente errado, a priori.

No segundo grupo de teorias, a saber, o inclusivismo, é como se houvesse religiosos de segunda classe que, apesar de não pertencerem aos 'iluminados', podem ter seu lugar ao sol, através da tese de que aqueles que conhecem a verdade, num gesto de caridade ou paternalismo, são capazes de acolher aqueles que não conhecem. De certa forma, tem-se uma tese exclusivista implícita na qual se mantém a ideia de que há um único sistema de crenças capaz de ter a verdade e de salvar a humanidade, apesar de que outros podem participar das verdades e da salvação do sistema correto. Mesmo assim, parece que cabe ao sistema "correto" decidir quem pode ser salvo e quem não pode, quem compartilha e quem não compartilha das verdades que o sistema diz possuir. Isso, em termos políticos, a meu ver, pode levar aos mesmos problemas do exclusivismo.

As teses pluralistas, por outro lado, parecem-me mais promissoras em termos de discussão da diversidade religiosa, pois, em primeiro lugar, reconhecem a diversidade religiosa como algo que não pode ser simplesmente deixada de lado nas discussões filosóficas e teológicas, além de afirmarem o fato de que as diferentes religiões parecem possuir, ao menos em um primeiro momento, legitimidade para afirmar o que afirmam. Mas antes de falarmos disso, é preciso reforçar a ideia de que entendo que uma perspectiva pluralista sobre a diversidade religiosa é extremamente importante em uma sociedade democrática, pois reconhece o direito de voz e vez a quem pensa diferente, como defensor de um determinado sistema de crenças. Uma perspectiva pluralista correta reconheceria a discordância como legítima e passível de ser discutida, o que favorece o diálogo entre diferentes formas de ver e entender o mundo. Ela não desprezaria o fato de que pode haver certas semelhanças e ideias comuns entre diferentes religiões, apesar de respeitar o fato de que nem todas as religiões compartilham as mesmas ideias. Neste sentido, um pluralista não precisaria tomar todo o sistema de crenças contrário ao seu 
sistema como a priori falso ou equivocado e não precisaria, também, abdicar do fato de que é possível discutir alguns pontos, algumas ideias contraditórias (SPICA, 2018) e isso é, sem dúvida, extremamente importante para uma sociedade democrática, pois pode fomentar novas ideias, novos debates e importantes contribuições para o sistema como um todo, o que não parece ser o caso nas perspectivas exclusivistas e inclusivistas.

Mostradas as vantagens de uma perspectiva pluralista para fomentar o diálogo inter-religioso, cabe agora mostrar como tal perspectiva se daria na prática democrática, como seria a posição de um pluralista em termos de religião no debate público e de como se daria a relação entre Estado e religiões. Porém, antes de fazer isso, gostaria de, brevemente, mostrar as razões do porquê as religiões deveriam ter lugar na esfera pública.

\section{Devem as religiões ter espaço na esfera pública?}

Muitos pensadores contemporâneos afirmam que há uma distância muito grande entre o ideal moderno de uma sociedade e Estado laicos e a realidade empírica que mostra uma sociedade com grande apelo religioso e Estados que, de forma mais ou menos abrangente, sofrem influências religiosas de todos os tipos ${ }^{8}$. Berger, por exemplo, afirma que o erro das teorias que pregavam a ideia de que as sociedades contemporâneas eram cada vez mais seculares é que elas imaginaram que o pluralismo de crenças e ideias era apenas mais um fator que sustentava a ideia de secularização. Porém, para ele,

\footnotetext{
O que aconteceu foi muito menos dramático: ficou cada vez mais evidente que os dados empíricos contradiziam a teoria. Com algumas exceções, particularmente a Europa e uma determinada intelectualidade internacional, o nosso mundo não é nada secular; ele é tão religioso como outrora, e em alguns lugares mais ainda (BERGER, 2017, p. 11).
}

Berger está fazendo uma constatação de fato, ou seja, as religiões têm grande influência nas sociedades e estados modernos. Mas a questão filosófica parece ser uma questão um pouco mais profunda, a saber, se há razões para defender que as religiões deveriam ter lugar na esfera pública. Muitos autores têm se debatido com esta questão, entre os quais incluem-se, por exemplo, Wolterstorff, Habermas, Rawls e Trigg, entre outros. Todos estes autores parecem reconhecer que a religião tem algum papel na esfera pública, no debate sobre os valores, rumos e objetivos das sociedades democráticas. Estes autores reconhecem que as religiões fazem afirmações e têm ideias importantes sobre aquilo que se chama bem público ou bem comum. Subjacente à essa ideia está a percepção 
de que a tese moderna de que a religião deveria ficar confinada à esfera privada não parece mais fazer sentido. Mas é possível defender isso? É possível afirmar que as religiões não são constituídas meramente de crenças pessoais, ou melhor, que elas deveriam ser entendidas não meramente como questão de crença pessoal, emoção ou coisa do gênero, mas como crenças que devem ser levadas em conta nos debates públicos?

Entendo que, para termos uma resposta filosoficamente consistente em relação a esta questão, é preciso perceber que a questão normativa (se a religião deve ser levada em conta no debate público) é dependente de uma questão epistemológica, ou seja, aquela que diz respeito ao fato de que se é possível dizer que as crenças religiosas de cunho prático (morais e políticas) podem ser encaradas como crenças razoáveis ou racionais ${ }^{9}$. Se a resposta for negativa, parece plenamente razoável confina-las à esfera privada, tratando-as como meramente uma questão de emoção, sentimento ou crença irracional. Porém, se a resposta for positiva temos de reconhecer o fato de que as crenças religiosas devem ter espaço no debate público, como todas as outras crenças práticas consideradas racionais ou razoáveis. Afinal, parece que a única coisa que se pede para que possamos entrar no debate público é razoabilidade e racionalidade e não, por exemplo, que todas as nossas crenças tenham passado pelo crivo da ciência ou sejam necessariamente verdadeiras.

Neste trabalho, vou, seguindo vários autores contemporâneos, como Habermas, Trigg e Wolterstorff, tomar como pressuposto que as religiões fazem afirmações sobre questões práticas que tendem a ser objetivamente válidas ${ }^{10} \mathrm{e}$, portanto, suas afirmações de crenças práticas devem ser levadas em conta na esfera pública. Mas estou justificado em partir deste pressuposto? Entendo que sim. Uma resposta contrária teria de assumir uma das seguintes alternativas: ou 1) crenças religiosas de cunho prático são injustificadas no sentido de que não há evidências suficientes a seu favor; 2) crenças religiosas de cunho prático são meramente uma questão de desejo pessoal, preferência, que não têm nada a ver com questões objetivas (são crenças produzidas por aparatos cognitivos que não se relacionam à produção de crenças que tendem a ser objetivamente válidas, mas por aparatos cognitivos que produzem desejo, emoções, etc); ou 3) crenças religiosas de cunho prático são visões distorcidas da realidade, uma espécie de loucura ou perversão diante do mundo. ${ }^{11}$

Não estou disposto a assumir (1) porque ele acarreta a ideia de que qualquer crença que uma pessoa possua só pode ser assumida por ela se essa pessoa tiver boas 
evidências para aquilo que acredita. Uma crença só é considerada como racional com base em evidências. Essa ideia é muito bem resumida pela famosa frase de William Clifford: "É sempre incorreto, em qualquer situação, para qualquer pessoa, acreditar seja no que for com base em indícios insuficientes" (CLIFFORD, 2010, p.108). Além de Clifford, outros autores como, Locke (2014) e Dawkins (2007), defendem esta posição. Há muitas formas de criticar tal posicionamento (JAMES, 2010; PLANTINGA, 2016), mas, para não tornar ainda mais longo o presente texto, vou me ater a uma forma que entendo ser a mais fácil de entender e uma das mais simples explicações de como soa absurdo pedir que tenhamos evidências para todas as nossas crenças. Tal crítica é elaborada por Mikael Stenmark. Ele afirma:

\begin{abstract}
Eu argumentei em outro contexto contra o evidencialismo e defendi que não é realmente racional para nós - dado o que nós e nossas afirmações somossermos evidencialistas. Por que? Para tornar curta um longa história, o constante questionamento de nossas crenças, a constante busca por evidências ou boas razões que o evidencialismo implica, não é um modo inteligente de os seres humanos governarem suas crenças, simplesmente porque elas não têm nem tempo nem recursos cognitivos necessários. Nós somos seres finitos com recursos cognitivos limitados. Isto implica que se nós queremos ser seres racionais, nós não podemos perder tempo e recursos para avaliar criticamente todas as nossas crenças. Tempo, memória e assim por diante são tão preciosos e qualquer desperdício destes recursos devem ser evitados. Alguém poderia, de fato, perder seu tempo inteiro buscando por evidências para todos os tipos de crenças. Contudo, o evidencialismo como uma atitude cognitiva básica ou como um modelo de racionalidade humana deveria ser rejeitado. Na verdade, parece como se a coisa mais racional para nós fazermos é continuar a acreditar no que nós já acreditamos sobre Deus, a vida, e o amor até nós encontrarmos boas razões para acreditar em algo a mais. Eu chamo este modelo de racionalidade de presuncionismo, porque ele é baseado sobre a afirmação de que nossos processos de formação de crença e suas declarações (de crença) deveriam ser presumidas como sendo intelectualmente inocentes até que se provem culpadas. Estes processos e suas declarações não precisam primeiramente ser justificados (i. e., providos de boas justificações) antes que seja racional para nós acreditar neles. A atitude inicial frente à nossas crenças deveria ser de confiança, não de desconfiança. (STENMARK, 2004, p. 89-90).
\end{abstract}

Basicamente, o que Stenmark está dizendo é que é absurdo que seja exigido de qualquer pessoa que ela busque evidências racionais para todas as suas crenças. Isso tornaria impossível qualquer progresso em termos científicos e de conhecimento comum de nosso dia-a-dia, pois a pessoa teria de, a todo momento, buscar por evidências para aquilo que acredita. Ora, isso a paralisaria e a tornaria capaz de fazer qualquer coisa.

Não estou disposto a assumir (2) porque isso acarretaria a comparação das crenças práticas religiosas a meras crenças subjetivas sem valor para discussões. Como bem expõe Trigg (2014, p. 17), “dizer que a religião não faz afirmações objetivas deve 
significar que ela não pode se preocupar com uma realidade objetiva, acessível a todos". Mas dizer que a religião não está preocupada com questões da realidade objetiva, é dizer que tudo o que ela afirma só tem validade para aquele que afirma. Dificilmente as religiões aceitariam isso ${ }^{12}$. Porque isso seria assumir que quando um religioso está dizendo que aprova ou desaprova questões práticas (morais e políticas), ele está fazendo uma asserção do mesmo tipo que quando ele afirma que gosta ou não de bananas. Ora, assim como no caso das bananas, estou obrigado a respeitar o gosto dele, mas nada posso fazer para que ele mude sua opinião e ele nada pode fazer para que eu goste ou não de bananas. Parece absurdo assumir que o religioso quando está a fazer afirmações de crenças práticas, esteja apenas me falando sobre seu gosto por tais crenças, isso levaria a um respeito vazio, que não levaria a nada em termos sociais. No fundo, ele está, assim como um não-religioso, assumindo que sua crença é válida objetivamente e deve ser discutida publicamente. É preciso deixar claro, porém, que ao dizer que as religiões fazem afirmações de crenças práticas que tendem à objetividade não estou dizendo que estas crenças são verdadeiras, elas também, ao assumir isso, terão de admitir a possibilidade de que podem estar em erro ${ }^{13}$.

Não estou disposto a assumir (3) porque isso implicaria dizer que o religioso, sempre que está a fazer afirmações de crenças práticas, as afirma devido a um defeito $\operatorname{cognitivo~}^{14}$ (no sentido de ser uma ilusão, uma loucura ou uma perspectiva distorcida da realidade). $\mathrm{Na}$ verdade, não estou disposto a assumir que o religioso comum, que faz todas as suas atividades cotidianas de acordo com aquilo que consideramos dentro da normalidade e que, em todas essas atividades, parece estar com seu aparato cognitivo funcionando corretamente, esteja, apenas quando se trata de questões religiosas, sofrendo de algum, por assim dizer, 'defeito cognitivo'. Dizer que as crenças religiosas são fruto de algum 'defeito cognitivo' levaria ao absurdo de ter de assumir que uma parte significativa da humanidade tem graves problemas em seu aparato cognitivo. Além disso, em termos práticos, teríamos grandes problemas no que se refere à imputabilidade moral e jurídica em caso de pessoas religiosas cometerem faltas morais ou jurídicas e alegarem que as cometeram por motivos religiosos. Teríamos de admitir que estas pessoas não estavam em pleno uso de suas faculdades racionais e, portanto, não são culpadas no sentido forte do termo.

A meu ver, então, parece que temos razões para dizer que as crenças religiosas de cunho prático tendem a ser objetivamente válidas e são produzidas por mentes capazes 
de produzir tais crenças e é, por isso, que elas deveriam ser consideradas no debate público, ${ }^{15}$ já que outras crenças práticas com esse mesmo status são consideradas.

\section{Diversidade e democracia: em busca de uma posição pluralista na esfera pública}

Diante do fato de que existem razões para se tomar as crenças práticas religiosas como crenças que tendem à objetividade e são produzidas por pessoas que possuem um aparato cognitivo funcionando corretamente, entendo que a questão principal e que causa maior divergência é a de como deveria se dar a participação das religiões na esfera pública. Essa questão se torna ainda mais difícil quando nos damos conta, como já fizemos acima, da diversidade religiosa e das diferentes respostas que podemos dar a esta diversidade. A questão que parece se colocar é: como agenciar as diferentes demandas, valores e ideais das diferentes religiões e destas com aquilo que se costuma chamar de razão pública ou razão laica? Entendo que a resposta a esta questão pressupõe dois níveis: um nível da sociedade civil: ou seja, como as diferentes religiões deveriam se comportar umas com as outras e em relação aos não religiosos e estes com os religiosos e um segundo nível de como o Estado deveria se comportar diante dos diversos sistemas de crenças, dado que a liberdade religiosa é um direito humano fundamental. Vou começar pelo primeiro.

\section{Diversidade e respeito}

A junção de uma perspectiva pluralista em relação à diversidade e a tese de que as religiões podem ter voz na esfera pública, no sentido de que elas não são discursos meramente subjetivos, privados e expressões de sentimentos pessoais, gera desafios importantes para as próprias religiões e sua relação entre elas, mas também na relação entre as religiões e os não religiosos e vice-versa. Por um lado, ao ganharem voz na esfera pública, as religiões precisam, em algum sentido, repensarem sua possibilidade de verdade única, pois é difícil conciliar democracia com a ideia de que eu sou o dono da verdade, pois se sou o dono, todas as outras "verdades" não importam. Coloco-me, à priori, em uma posição de divulgador da verdade e não em uma posição de diálogo, o qual é imprescindível em uma sociedade democrática. Ao questionarem a ideia de que sua verdade é a única verdade completa, por outro lado, as religiões correm o risco de 
relativizarem demais suas crenças a ponto de afirmarem que tudo vale e nada vale e, assim, abandonarem aspectos essenciais de seu sistema de crenças.

Roger Trigg afirma que o conhecimento de discordâncias não leva necessariamente ao ceticismo ou relativismo quanto à possibilidade da verdade. Ele ressalta o fato, com o qual estou de acordo, que o desacordo é comum em áreas não religiosas como a ciência e nestas áreas a simples existência da discordância não leva necessariamente ao abandono das ideias e compromissos que possuímos. Um exemplo interessante que poderíamos dar para ilustrar a tese de Trigg é o de debates científicos ou filosóficos em congressos. É difícil ver cientistas ou filósofos abandonarem rapidamente suas ideias simplesmente porque um terceiro discorda deles. O caminho da discordância à mudança de ideias ou para o fato de que tudo vale é muito longo e, às vezes, perigoso. No fundo, não abandonamos tão rapidamente nosso sistema de crenças, simplesmente ao ver que há discordâncias, tanto na esfera religiosa, quanto em outras áreas, se assim o fizéssemos, afirma Trigg, provavelmente ficaríamos paralisados em nossas crenças e ações.

A vida humana não é estranha à discordância em todos os modos de vida e em todas as questões. Uma vez que nós nos retiramos para o agnosticismo ou ceticismo em face dela, mesmo em esferas ordinariamente não religiosas, o resultado será paralisia e talvez uma conclusão niilista de que nada é verdade (2014, p. 88).

A solução de Trigg é propor uma espécie de humildade epistêmica que parte do fato de que, como seres humanos, precisamos reconhecer que temos menos do que um entendimento completo do que é a verdade (TRIGG, 2014, p. 116), sem com isso dizer que a verdade é impossível ou que tudo vale. Uma ideia como essa pode favorecer o fato de que os participantes dos diferentes sistemas de crenças podem ouvir uns aos outros ao mesmo tempo que evita o absolutismo, já que nenhum sistema de crenças é dono da verdade absoluta e, então, não precisa coagir outros a aceitar sua verdade. Para Trigg (2014, p. 124), a questão fundamental no diálogo inter-religioso não é se há uma verdade já estabelecida que outros devem aceitar, mas uma posição de humildade que pergunta como podemos estar certos do que é a verdade. Essas ideias de Trigg, a meu ver, estão de acordo com a noção de pluralismo que defendi acima, a saber, um pluralismo que é aberto à possibilidade de entendimento entre as diferentes religiões e que compartilha com a ideia de que a posição epistemológica em relação a sistemas de crenças adversários não é o de tentar a todo momento negar a validade ou derrotar o sistema como um todo, mas 
discutir temas e questões pontuais dentro de cada sistema, assumindo que tais questões também podem ser razoáveis.

As ideias de Trigg levam à importante conclusão de que, numa sociedade plural, não pode existir um sistema de crenças que dita as regras a todos os outros sistemas, a partir de uma posição exclusivista, de forma monológica, apesar de poder haver espaço para todos os discursos. Nesse sentido, as religiões, na contemporaneidade, precisam perceber que não ocupam o centro, mas que vivem num mundo sem centro, num mundo onde todos podem fazer seus discursos de forma legítima ${ }^{16}$. Como bem constata Sacks:

\begin{abstract}
Numa sociedade plural - e mais ainda num mundo plural -, cada um de nós tem de se satisfazer com menos do que quando nos associamos com companheiros de crença. [...] O que perdemos é amplamente compensado pelo fato de nos tornarmos coarquitetos de uma sociedade maior do que a que seríamos capazes de construir sozinhos, uma sociedade na qual a nossa voz é ouvida e considerada ainda que não predomine.” (SACKS, 2013, p. 94).
\end{abstract}

É importante aqui, fazer uma diferenciação que, a meu ver, é útil para o debate da relação entre diferentes sistemas de crenças. Em uma sociedade plural, precisamos diferenciar o conceito participação do conceito imposição. Entendo que uma determinada pessoa ou grupo de pessoas que compartilha crenças, valores e práticas está participando quando é parte ativa de um debate que envolve discordâncias. No caso de sociedades democráticas, a pessoa ou grupo está participando quando é reconhecida e está integrada nos processos de definição, deliberação, apresentação de alternativas e tomadas de decisões, seja participando de conselhos, de órgãos de debate público, órgãos consultivos, opinando e sendo parte das decisões de maneira democrática, dando a conhecer suas reinvindicações, cultura e modo de vida, ao mesmo tempo que se coloca numa posição de humildade epistêmica, reconhecendo que não é dono de uma verdade absoluta e ouve e respeita as reivindicações, cultura e modos de vida de outra pessoa ou grupo de pessoas que participa ativamente do debate. Isso não é mera tolerância, no sentido de suportar a existência do outro passivamente quase que com indiferença, mas uma questão de respeito, no sentido de interesse em compreender os discursos, razões e modos de vida dos outros.

Por outro lado, uma pessoa ou grupo de pessoas, participando de um debate que envolve discordância, está impondo uma verdade quando busca determinar monologicamente uma suposta verdade como aquela que é a que todos devem seguir, 
quando está tentando definir de forma monológica as políticas do Estado; impor seu modo de vida como o único verdadeiro, seja considerando o discurso de oposição como irracional ou sem valor, seja usando da força física ou do próprio Estado. A imposição é própria de sistemas fundamentalistas que acreditam que são donos da verdade e que esta verdade precisa, de todas as formas, ser imposta aos demais membros de uma sociedade, não se importando com o fato de que há discordâncias.

É importante ressaltar aqui que esta diferenciação entre participação e imposição apresenta um limite claro para a liberdade religiosa. Ela é permitida e deve até ser incentivada pelas sociedades democráticas, mas a sociedade democrática não pode permitir que uma determinada religião determine, de forma monológica, que todos são obrigados a seguir uma única verdade. Isso se deve ao fato de que a imposição de uma única verdade tende a levar ao fim da própria democracia, a qual se baseia na ideia de que o sujeito é livre para escolher seus modos de vida e suas crenças. Se somos obrigados a seguir determinado modo de vida, logicamente não temos escolha alguma e, então, a própria democracia está em cheque. Neste sentido, temos um limitador à participação dos sistemas religiosos bem como de todos os sistemas de crenças, inclusive os sistemas não religiosos, e indivíduos numa sociedade democrática e plural. O limitador é a própria democracia. Ao mesmo tempo que ela, por causa de seus ideais de liberdade individual e de crença, permite o surgimento e manutenção de diferentes sistemas de crenças, ela limita esses diferentes sistemas ao dar prioridade a ela, já que outro tipo de sistema político pode levar à derrocada do pluralismo e à imposição de um único sistema de crenças como o verdadeiro. Temos, assim, um princípio comum regulador da participação no debate público que basicamente mostraria que a pluralidade é levada a sério somente se a participação plural não for tomada como forma de imposição exclusivista. $\mathrm{Na}$ verdade, aqui chegamos a uma ideia de diálogo inter-religioso no qual, partindo de uma atitude de humildade epistêmica, reconhecemos que, como seres humanos, podemos não ter o controle total da verdade e o abrir-se à diferentes perspectivas pode ajudar a chegarmos mais próximo de uma visão completa de mundo. Isso não quer dizer que as religiões precisam, para entrar no debate público, abandonar ou transformar suas crenças, mas apenas e tão somente colocarem-se numa atitude de diálogo plural. Em algum sentido, é claro, as religiões precisarão encontrar internamente a elas justificativas para fazer isso, precisarão encontrar nas suas próprias doutrinas justificações para entrarem no debate público. ${ }^{17}$ 
Essa ideia de que a democracia, ela mesma, é limitadora e reguladora de algumas posições na esfera pública também é, já, uma limitadora para aquilo que pode ser considerado (de um ponto de vista prático) como realmente uma posição plural. Ela elimina posições religiosas que, a priori, defendem, por exemplo, a eliminação de todas as outras religiões. Uma tal posição é inaceitável, pois nega a própria possibilidade de diálogo entre diferentes sistemas.

A humildade epistêmica e o princípio de respeito à democracia não deve ser aplicada apenas aos religiosos, mas também à parte da sociedade não religiosa. Esta também precisa tomar a religião a sério, tomá-la como um conjunto de crenças não meramente subjetivas ou irracionais, mas como crenças que têm validade e podem ser defendidas dentro do debate público, mesmo que não se concorde com elas. Aqui, a meu ver, é preciso chamar a atenção para o fato, muitas vezes deixado de lado nos debates sobre a religião na esfera pública ${ }^{18}$, de que a razão secular, na prática, toma a forma de várias razões. Há um pluralismo de crenças interno ao conjunto de pessoas que se dizem seculares ${ }^{19}$, assim como o há no que chamamos de religião. Elas defendem ou justificam suas crenças de modos diversos, tanto epistemicamente, quanto moralmente e politicamente e isso não é difícil de perceber e também é um fato que pode gerar grande desacordo ou mesmo violência. Neste sentido, a ideia de humildade epistêmica vale tanto para as relações entre as diferentes secularidades, quanto destas para com as diferentes religiões.

Entendo que, com o que foi dito até aqui, fica claro que uma posição plural diante da diversidade se mostra imperativa para que se possa fomentar o diálogo entre os diversos sistemas de crenças nas sociedades democráticas contemporâneas. Este pluralismo precisa ser um pluralismo que não meramente aceite a existência da diversidade, mas que, como vimos, a respeite e se coloque em uma posição epistêmica de diálogo. Mas, se isto é possível e, mais, se é possível a participação dos diferentes sistemas religiosos no debate público em uma sociedade democrática, temos que nos perguntar como o Estado deve agenciar este debate e qual a relação que o Estado e as diferentes religiões devem ter no que tange a definição de normas, objetivos e políticas públicas por parte do Estado.

\section{Estado e diversidade religiosa}


Dada a imensa diversidade de crenças e instituições religiosas presente no mundo atual surge uma questão bastante importante no que tange ao Estado, é possível, diante deste cenário, defender o ideal moderno de um Estado laico, entendido aqui como um Estado neutro em relação às diferentes religiões, e se este é o tipo de Estado que melhor responde aos desafios de uma sociedade plural.

A melhor forma de responder estas questões, é, a meu ver, entender alguns desafios que o Estado laico possui em uma sociedade marcadamente pluralista. A meu ver, um dos grandes desafios é que, ao se colocar como neutro em relação às religiões, o Estado pode desconsiderar a possibilidade de que as religiões tenham algo a dizer sobre o bem público, transformando-as em mera preferência pessoal e, dessa forma, a religião não teria nada a dizer e a contribuir no debate sobre os rumos das políticas de Estado. $\mathrm{O}$ desafio, parece, então o de como conciliar neutralidade com reconhecimento de que a religião tem papel no debate público. Não se pode negar que muitas vezes o Estado laico é entendido como laicismo, no sentido de uma ideologia que prega que as manifestações religiosas não passam de expressões subjetivas que não têm nada de objetivo a dizer e que, portanto, devem se restringir à esfera privada. Um Estado laico neste sentido pode levar à exclusão da religião do debate público e desconsiderar parte importante das crenças pessoais das pessoas e, em consequência, gerar um sentimento de privilégio para um grupo, os não-religiosos, no debate democrático.

Roger Trigg (2014, p. 176ss) chama a atenção para o fato de que ao tratar todas as religiões como questão de mera preferência pessoal, o Estado já define o status da religião na esfera pública, o define como um discurso sem importância para a sociedade como um todo e, ao fazer isso, parece ferir um ideal de sociedade livre. A lógica para a qual Trigg chama atenção é simples. As religiões possuem visões do que é uma boa sociedade ou uma sociedade justa, ao tomar essas visões como preferências irracionais que não merecem espaço nas discussões dos rumos políticos de uma sociedade, o Estado condena as pessoas a não terem o direito de defenderem suas posições a respeito dos rumos da sociedade. Dificilmente as pessoas aceitam isso e tal posição do Estado pode gerar mais conflitos do que evitá-los. A religião, para Trigg (2014, p.186),

[...]tem relevância política, não somente porque ela cria problemas em sociedades divididas, mas também porque ela pode contribuir para o debate público concernente ao que constitui o bem e o mal-estar humano. Mesmo se algumas formas de religião podem ser nocivas, envolve-las no debate ajudará 
a expor isso. A outra alternativa é permitir que elas se sintam invisíveis e não desafiadas.

Outro desafio a um Estado supostamente neutro em relação à religião é o fato de que, em muitos momentos, haverá conflitos entre normas religiosas e normas estatais e, quando isso acontece, parece haver uma preponderância do Estado em relação às instituições religiosas e isso pode ser entendido como uma forma de interferência do Estado em questões religiosas ou, novamente, como laicismo, interferência de uma ideologia não religiosa em questões religiosas. Na verdade, a questão é: como conciliar liberdade religiosa com as normas e princípios de um Estado laico sem com isso ferir o ideal de liberdade religiosa?

A diferenciação, feita por Wolterstorff (2012, p. 298-299) entre liberdade de religião e liberdade para as religiões parece ser bastante útil aqui. O primeiro caso, Wolterstorff afirma, refere-se à liberdade das pessoas tomarem parte em atividades religiosas, a liberdade de instituir instituições religiosas, a liberdade de educar os filhos religiosamente e a liberdade de apresentar suas crenças a outros mesmos que a não crentes. Já a liberdade para a religião é aquela que se refere à participação ou exercício da religião para além das atividades mencionadas acima, refere-se ao fato de os religiosos realizarem diferentes atividades em locais diferentes que não religiosos e mesmo assim o realizarem sob um ponto de vista religioso. No fundo é engajar-se em atividades nãoreligiosas em um modo religioso.

No primeiro caso, o da liberdade de religião, refere-se ao direito que protege o indivíduo e as religiões da interferência do Estado, é uma proteção aos religiosos do poder do Estado. É bem sabido que o princípio de liberdade religiosa é um direito humano fundamental expresso no artigo XVIII da Declaração Universal dos Direitos Humanos. Neste sentido, uma nação democrática e signatária dos direitos humanos deve garantir tal liberdade, tal qual expressa na declaração. Apesar da ideia de liberdade religiosa ser um ponto que parece pacífico, ela não o é na prática. Podemos citar vários exemplos de problemas que as sociedades democráticas têm quando se trata de liberdade religiosa. Uma análise cuidadosa da própria Declaração Universal dos Direitos Humanos mostra que há direitos individuais que certos estados democráticos defendem que poderiam entrar em conflito com a liberdade religiosa. Veja-se, apenas como um exemplo, a questão dos direitos das mulheres. Deve o Estado interferir nas religiões quando estas defendem que homens e mulheres não têm os mesmos direitos e forçar uma mudança na doutrina 
religiosa? Se sim, o Estado não estaria ferindo a liberdade religiosa? Se não, o Estado não estaria sendo conivente com a quebra do ideal de direitos iguais entre homens e mulheres? Outro problema pode surgir se o Estado aceita que as religiões têm visões legítimas sobre o bem ou mal-estar das sociedades ( que suas crenças sobre a sociedade não são meramente subjetivas e/ou irracionais), já que isso pareceria dar o direito ao religioso de defender em instituições estatais (poder legislativo, por exemplo), valores e ideais tipicamente religiosos ${ }^{20}$.

O segundo caso, o da liberdade para as religiões, refere-se muito mais a uma questão de possíveis privilégios, ou seja, o de como evitar privilégios a um grupo religioso ou não religioso na participação e tomada de decisões do Estado. Wolterstorff (2012, p. 299) diz que há dois modos nos quais o religioso pode tomar parte em atividades não religiosas de modo religioso. A primeira seria através da criação e manutenção de instituições religiosas que desempenham atividades que extrapolam os limites das atividades tipicamente religiosas, como, por exemplo, escolas, hospitais e universidades. A segunda é o de engajar-se religiosamente em atividades ou instituições tipicamente não religiosas. No primeiro caso, a questão ficaria mais restrita ao financiamento público das instituições religiosas e a da normatização destas instituições. Deveria o Estado financiar e ajudar estas instituições? Uma solução seria dizer que, em uma perspectiva pluralista, se o Estado financia uma instituição, financia todas as instituições religiosas, não privilegiando instituições de um determinado grupo religioso. Outra seria a de se isentar de qualquer financiamento ou ajuda a essas instituições, com a justificativa de que elas são alternativas aos serviços já ofertados pelo Estado e, então, o Estado não tem o dever de financiar tais instituições. No que tange às regras que estas instituições devem seguir, a questão fica mais complicada. Por exemplo, deveria um Estado que defende o suicídio assistido exigir de um hospital religioso que tem entre suas doutrinas a não realização de suicídio assistido e que não recebe recursos do Estado que este realize suicídio assistido? Ou, deveria o Estado exigir que escolas tipicamente religiosas, sem nenhum tipo de incentivo do Estado, deem suas aulas de ensino religioso em uma perspectiva pluralista? A meu ver, uma saída para a questão seria a de que o Estado não interfere em instituições que não recebem nenhum suporte do Estado ${ }^{21}$, já as instituições que recebem suporte do Estado precisam, necessariamente, adotar uma perspectiva pluralista.

No segundo caso, a de sujeitos que se engajam em atividades não religiosas de um modo religioso, a questão torna-se complexa, pois não se pode esquecer que um 
religioso não é apenas um religioso, mas um ser-humano comum que precisa e tem direito a estudar, trabalhar, alimentar-se e locomover-se, por exemplo. Como deveria o Estado agir em questões básicas como esta? Já vimos que o Estado não poderia interferir na liberdade de religião do sujeito, mas têm as diversas manifestações religiosas o direito de exigir que suas tradições, crenças e costumes sejam aceitos e respeitados em instâncias não religiosas? Um exemplo simples é o de algumas religiões que têm, entre suas crenças fundamentais, um dia específico da semana para descanso e/ou oração ${ }^{22}$. Essa crença pode estar em conflito com ideais laicos de trabalho e pode, inclusive, ser usado para dizer que tal crença prejudica a economia de um país, já que interfere na organização do trabalho das empresas. Lembrem-se que numa sociedade plural, podemos ter diversas religiões que consideram dias e/ou momentos diferentes de cada dia como sagrados. Deveria o Estado interferir nisso e determinar um dia de descanso arbitrário ou exigir das empresas, escolas e afins que elas respeitem a crença de cada religião? Se sim, estaria o Estado privilegiando as religiões em detrimento de crenças não-religiosas? Se não, estaria o Estado interferindo em questões fundamentais de certas doutrinas religiosas? A solução para questões como estas seria incluir no debate das instituições estatais, nos órgãos estatais que definem políticas, leis, regras e valores e sua aplicação, a voz das religiões. Tal inclusão facilitaria a compreensão do discurso religioso por parte do Estado e o debate seria o mais amplo possível.

Não tenho tempo aqui de discutir todos os problemas e desafios que a diversidade religiosa traz para a noção de Estado laico. Os exemplos que trouxemos servem apenas para ilustrar o quão complexo é defender, atualmente, uma ideia de neutralidade do Estado. $\mathrm{O}$ fato da diversidade social da atualidade juntamente com o crescente consenso de que a as religiões podem e têm direitos de participar no debate público parece que leva a uma necessidade inclusive de se pensar o conceito de Estado para as democracias plurais. Se, por um lado, não é fácil para as sociedades democráticas abrir mão de uma separação entre igreja e Estado, dado a enormidade de exemplos históricos que mostram quão perigosa é esta união, por outro lado, não se pode negar que dependendo da forma como a laicidade do Estado é entendida, ela pode sim privilegiar grupos não-religiosos e mesmo ferir a liberdade de crença religiosa.

Uma solução seria assumir que igreja e Estado não devem ser instituições unidas, até porque, no mundo contemporâneo ocidental, a noção de igreja está no plural: são diversas igrejas em um único Estado e a associação institucional de uma determinada 
igreja com o Estado poderia levar à impossibilidade de convivência pacífica de diferentes instituições religiosas dentro do Estado. Assumir essa posição, porém, não leva necessariamente ao fato de que o Estado deva ser completamente neutro em questões religiosas, no sentido, de não aceitar nem mesmo o debate de cunho religioso em suas instâncias ou exigir que os religiosos deixem suas crenças em casa ao assumirem qualquer função no espaço público. Ao invés de exigir isso, caberia ao Estado fomentar a diversidade, proteger os direitos de todos manifestarem-se e discutirem questões religiosas, mesmo em espaços públicos. Essa perspectiva de um Estado plural teria a vantagem de desafiar tanto as razões laicas quanto as razões religiosas, dado que ambas estariam participando do debate e seriam forçadas a buscar dentro de seus próprios sistemas de crenças, as justificativas para se manterem no debate público. Não haveria aqui, privilégio a nenhuma das razões, nem se forçaria nas pessoas a ideia de que existe um único modo racional de se discutir as questões políticas e os rumos do Estado, mas modos plurais de entendimento do próprio Estado. ${ }^{23}$

Alguém poderia questionar que idealmente isso parece interessante, mas na prática ela levaria a uma eterna discussão sem que se chegasse a consensos e, então, as decisões do Estado estariam prejudicadas. Em minha visão, a resposta a este possível questionamento é o entendimento de que a democracia é um processo de construção constante e que nem sempre implica progresso constante, ela não é uma obra pronta e, mais do que de consensos, uma sociedade democrática é construída sob a base do respeito à discordância. Além disso, na democracia, as decisões são tomadas a partir de votações e, nestas, há vencedores e perdedores, os vencedores de uma votação podem ser os perdedores de outra, certos grupos religiosos podem ganhar uma e perder outra para outros grupos religiosos e não-religiosos, o que pode gerar mudanças tanto para um lado quanto para outro. E isto, desde que não implique numa quebra da democracia, deveria ser encarado como normal numa democracia que se pretende realmente plural ${ }^{24}$.

É claro que alguém poderia dizer que deixar tudo na mão do voto pode levar ao fim da democracia, já que dado que a maioria das pessoas são religiosas, provavelmente, as ideias religiosas se sobressairiam às ideias laicas e, mais do que isso, os grupos maioritários em termos religiosos tornariam rapidamente o estado democrático em estado teocrático. Antes de mais nada, é preciso dizer que este é um perigo sempre presente em toda a democracia: há sempre o perigo de um grupo maioritário (religioso ou não) assumir o poder e começar a impor suas vontades, oprimindo minorias e isso pode acontecer tanto 
em democracias que levam em conta as crenças práticas das religiões, como em sociedades que entendem que a religião não pode participar do debate público. A única saída, a meu ver, é justamente a criação de instituições democráticas fortes que não permitam que isso aconteça e o fomento de uma cultura de respeito à democracia. Afinal, parece claro que democracia não é meramente um sistema de governo, mas uma cultura ou modo de vida (TOURAINE, 1996, p. 175), que precisa ser cultivado como tal e, como já falei antes, para participar dela é preciso, antes de tudo, respeitá-la. Novamente, preciso dizer, assim como o fiz anteriormente, que caberá às religiões encontrarem justificativas internas a elas para convencerem-se de que podem e devem cultivar um modo de vida democrático. Caso contrário sofrerão o ônus de não serem levadas em conta na esfera pública e serem tratadas meramente como crenças pessoais, sem valor objetivo.

Para finalizar, quero recordar o objetivo do presente ensaio. Ele busca apresentar a necessidade de uma perspectiva pluralista no debate público em sociedades democráticas. Essa perspectiva pluralista, como vimos, também está em constante construção, por isso entendemos que o texto não resolve todas as questões, apenas apresenta alguns desafios que sociedades que se dizem plurais precisam enfrentar. Neste sentido, as discussões aqui apresentadas não pretendem ser definitivas, mas provocativas, no sentido de manter o debate sobre os desafios que a pluralidade religiosa traz às democracias contemporâneas. 


\section{Notas}

${ }^{1}$ Professor Associado da Universidade Estadual do Centro- Oeste - UNICENTRO, Guarapuava, P.R., Brasil, e membro do corpo docente do Programa de Pós-Graduação em Filosofia da UNIOESTE, Toledo, P.R., Brasil. E-mail: marciano.spica@gmail.com

${ }^{2}$ Alguns autores trabalham com uma divisão ainda maior, colocando, por exemplo, o relativismo como mais uma posição filosófica a respeito da diversidade. Ver, por exemplo: (RUNZO, 2010, pp. 61-76).

${ }^{3}$ Essa é uma definição que está de acordo com o entendimento de Plantinga, 2000, p.175.

${ }^{4}$ Veja-se, por exemplo, o inclusivismo de Karl Rahner e sua diferenciação entre os cristãos que expressam sua fé e os cristãos 'anônimos', aqueles que, apesar de não professarem uma fé cristã, vivem de acordo com ela. Apesar de parecer uma tese abrangente, Rahner defende que somente o cristianismo possui um modo de vida capaz de levar à salvação. Quem vive esse modo de vida, mesmo que não professe ser um cristão será salvo. Isso é uma defesa de que o cristianismo está em uma posição privilegiada em relação às outras crenças, ou seja, somente o cristianismo atingiu a "realização histórica plena". (RAHNER, 2008. p. 400).

${ }^{5}$ É preciso deixar claro que Hick não tem uma perspectiva kantiana a respeito da religião, nem mesmo afirma que se poderia derivar uma teoria pluralista a partir de Kant, ele está apenas e tão somente fazendo uso de dois conceitos kantianos. Como ele mesmo afirma: "Kant estava discutindo percepção sensível e não aplica a distinção à religião - sua própria filosofia da religião era totalmente diferente e ele presumivelmente não teria aprovado o uso de tal distinção feita pelos pluralistas religiosos do século XX e século XXI. A distinção entre a realidade em si e a mesma realidade como um objeto da consciência humana, com a indispensável contribuição que a atividade humana faz, é o único aspecto de sua filosofia que eu pegarei emprestado, não precisamos (ou necessitamos) da totalidade de seu complexo sistema arquitetônico de formas e categorias" (HICK, 2010, p. 163). Diante disso, não vamos analisar, aqui, se tal uso poderia ou não ser legítimo de um ponto de vista kantiano.

${ }^{6}$ Uma crítica mais detalhada às teorias de Hick e Harrison foi realizada em Spica, M. A. Pluralidade e diálogo inter-religioso: possibilidades e limites das atuais abordagens pluralistas (no prelo).

${ }^{7}$ Uma discussão mais aprofundada desta questão encontra-se em: (SPICA, 2018)

${ }^{8}$ Veit Bader, por exemplo, em seu artigo Religious Diversity and Democratic Institutional Pluralism afirma que os filósofos políticos deveriam aprender duas coisas com a sociologia crítica da religião: 1)“Muitas das sociedades modernas são normalmente entendidas como 'secular', mas contrariamente à mitologia predominante, nós não podemos detectar qualquer declínio inevitável das crenças e práticas religiosas, nem qualquer privatização inevitável da religião nas sociedades modernas. 2) [Há variadas relações entre igreja e Estado nas sociedade ocidentais que podem ser verificadas empiricamente] "Esta diversidade é também a característica em arranjos constitucionais, legais, administrativos e culturais contraditórios, mesmo em Estados em que todos compartilham dos princípios liberais.” (BADER, 2002, p. 268).

\footnotetext{
${ }^{9}$ Não estou preocupado, aqui, com a verdade das crenças religiosas, pois entendo que no debate público a verdade é algo a ser alcançado e não pressuposto para entrar no debate. Explicando melhor, para entrar no debate público exige-se que as crenças sejam racionais e razoáveis e que tendam à verdade e não que elas sejam verdadeiras a priori ao debate público. O debate público ocorre, geralmente, por causa de discordâncias a respeito do que é certo, verdadeiro ou correto para a sociedade. A exigência de racionalidade e razoabilidade parece mais do que suficiente para que se possa discutir discordâncias de modo a chegar a novas concordâncias a respeito do certo, verdadeiro ou correto para a sociedade.
}

${ }^{10}$ É importante ressaltar que estou dizendo, apenas, que assumo que as diversas religiões são capazes de crença prática objetiva, são capazes de fazer afirmações sobre a vida prática (moral e política) que tendem a ser objetivamente válidas. Não estou com isso defendendo que as afirmações de crenças práticas religiosas são verdadeiras, apenas dizendo que as religiões fazem afirmações que elas acreditam ser válidas para os religiosos pertencentes à sua religião e, também, aos não pertencentes. Elas são afirmações acessíveis a todos. Além disso, não estou usando aqui o critério de objetividade científica pelo simples fato de que 
entendo que as afirmações de cunho prático (morais e políticas) não necessariamente passam pelo crivo da ciência ou têm um estatuto de cientificidade. Defender que todas as nossas afirmações em âmbito moral e político devem ser afirmações cientificamente aceitas é, no mínimo, defender um cientismo tosco ou, na pior das hipóteses, uma questão de injustiça epistêmica, já que se pede isso do religioso, mas dificilmente a cientificidade é um critério requerido a todos os argumentos laicos em termos práticos.

11 Estou adaptando à esfera prática parte das discussões de Alvin Plantinga sobre a racionalidade e razoabilidade da crença religiosa (PLANTINGA, 2016). Não estou, contudo, comprometendo-me com toda a sua teoria (por exemplo, não me comprometo com a ideia de que as crenças religiosas têm garantia). Além disso, os exemplos que apresento de oposição à racionalidade e razoabilidade à crença religiosa, são exemplos muito comum em qualquer debate sobre o estatuto epistemológico da crença religiosa. Em geral, as pessoas costumam dizer, para atacar a crença religiosa, que ela é irracional, - no sentido de ser um apego apaixonado a uma crença (um salto na fé) e que essa crença não é justificada no sentido de que o crente não tem evidências para sua crença, - ou que ela não tem nada a ver com objetividade, mas são crenças emocionais ou de sentimento, ou que a crença religiosa é fruto de uma mente distorcida que não vê o mundo como ele realmente é.

${ }^{12}$ Uma boa prova disso, é a vasta produção literária contemporânea sobre a razoabilidade e racionalidade da crença religiosa. A maioria desta literatura é desenvolvida por autores religiosos que não aceitam o fato da crença religiosa ser irracional ou subjetiva. (Dentre a vasta produção, podemos destacar, por exemplo, PLANTINGA \& WOLSTERSTORFF, 2009; SWINBURNE, 2015; ALSTON, 2015 e vários outros). Não é nosso objetivo aqui avaliar se tais teses são ou não consistentes (não teríamos nem espaço para isso). Porém, é importante ressaltar que, no mínimo, os argumentos para a razoabilidade e racionalidade das crenças religiosas são bastante sofisticados e atacam de frente algumas teses tradicionais de que a crença religiosa é meramente uma questão de preferência pessoal, ou uma visão distorcida da realidade ou uma ilusão que nos ajuda a lidar com um mundo cruel. Boa parte deste material produzido se atém à razoabilidade e racionalidade da crença em Deus, mas é preciso deixar claro que esse não é nosso problema aqui. Independentemente da crença em Deus, ser, para as religiões teístas, verdadeira ou não, entendo que é uma questão de fato que as religiões possuem crenças de cunho prático sobre a sociedade humana e que tais crenças têm pretensão de objetividade (crenças sobre o bem comum, os rumos da humanidade e a organização social, etc.). Diante disso, essas são as questões que devem ser avaliadas como razoáveis ou racionais, para fins de argumentação da participação ou não da religião na esfera pública. Um ponto importante a perceber, também, é o fato de que até mesmo ateus como Dawkins, na obra acima citada, concorda que afirmações religiosas tendem à objetividade, porém estão erradas, são falsas. Para se dizer que uma crença religiosa é falsa é preciso admitir sua pretensão de verdade. Da mesma forma para dizer que uma crença religiosa prática (moral e/ou política) é errada, precisa-se admitir que ela tende a ser objetiva, senão não temos nem porque discuti-las.

${ }^{13}$ Isso ficará mais claro na próxima seção.

14 Aqui trato a ideia de defeito cognitivo no sentido que Plantinga o faz na obra Conhecimento e crença cristã. Nela, Plantinga afirma que nossos órgãos se desenvolveram (ou foram produzidos) de tal forma que eles tendem a fazer as coisas de acordo com um certo fim e, tacitamente, dizemos que um órgão está funcionando se ele cumpre o fim para o qual foi desenvolvido. Por exemplo, dizemos que nosso olho está bom (funcionando corretamente) quando ele faz aquilo para que foi desenvolvido, ou seja, quando ele está nos fazendo ver corretamente (e está com defeito, quando não está nos fazendo ver corretamente). O mesmo acontece com nosso aparato cognitivo: ele está com defeito quando falha em produzir aquilo para o qual ele foi desenvolvido para produzir. Ver; (PLANTINGA, 2016, cap. 2 a 4).

${ }^{15}$ Não estou afirmando, com isso, que todas as crenças religiosas são razoáveis e racionais. Ora, da mesma forma que existem crenças não-religiosas que são consideradas irracionais e irrazoáveis e a humanidade desenvolveu modos de identificar isso, certas crenças religiosas também podem ser irracionais ou irrazoáveis. E este é mais um motivo para debatê-las na esfera pública, pois ao se fazerem presentes no debate podem ser avaliadas e consideradas como razoáveis ou não. Agora, dizer que uma crença prática é irrazoável ou irracional simplesmente porque tem base religiosa é bastante estranho tanto em termos epistemológicos quanto políticos.

${ }^{16}$ Uma discussão mais detalhada desta ideia encontra-se em: (Spica, 2014. pp. 317-336). 
${ }^{17}$ Adotar uma posição de diálogo, de humildade epistêmica, não é o mesmo que transformar a perspectiva toda de um sistema com padrões de um sistema alheio. Esta é uma posição que se distancia, a meu ver, da ideia habermasiana de que a religião precisa transformar sua consciência cognitiva ao entrar no debate público (HABERMAS, 2007, p. 155). Habermas parece sofrer, neste sentido, da ilusão de que existe uma razão laica unificada, à qual as religiões precisam se conformar para entrar no debate público e esquece-se, como veremos mais adiante, que a razão laica também é diversa e não constitui uma única racionalidade. Para uma crítica mais detalhada à posição de Habermas ver: (WOLSTERSTORFF, 2012, pp. 353- 376).

18 Toma-se como fato dado as discordâncias religiosas e se compara as religiões com a razão laica, quando, na verdade, a laicidade toma várias formas. É interessante perceber que, em filosofia da religião, o fato da diversidade religiosa é, muitas vezes, tratado como um negador para a própria religião, ou seja, a diversidade, mostraria a impossibilidade da razão religiosa, porém a diversidade de razões laicas não é tomada tão a sério como um negador desta, com raras exceções. Não estou com isso dizendo que a diversidade deve ser um negador tanto da razão laica quanto da religiosa, mas apenas chamando a atenção para o fato de que a laicidade deveria também ser tratada no plural, assim como tratamos as religiões.

${ }^{19}$ Veja-se, por exemplo, as várias perspectivas éticas (utilitarismos, kantismos, intuicionismos, éticas de virtudes etc.) e políticas (comunismo, socialismo, social democracia, neoliberalismo, etc) que temos no mundo contemporâneo. Neste sentido Engelhardt tem razão ao afirmar que a moderna "tentativa de sustentar um equivalente secular do monoteísmo cristão ocidental, por meio da revelação de uma única moral e narrativa metafísica da realidade, fragmentou-se em politeísmo de perspectivas, com seu caos de diversidade moral e sua cacofonia de numerosas narrativas morais concorrentes. [...] A racionalidade secular surge triunfante. Mas transformou-se em muitas racionalidades.” (ENGELHARDT, 2008, p. 30.)

${ }^{20}$ Isso poderia ser tratado como liberdade para a religião e não liberdade de religião, mas trato aqui como liberdade de religião porque entendo que se determinada religião tem como parte de sua doutrina a construção de, por exemplo, uma sociedade ideal, ela poderia pelo princípio de liberdade religiosa expor seu ideal a todos, mesmo aos não crentes.

${ }^{21}$ Ao afirmar isso, não estou dizendo que as instituições religiosas não deveriam adotar, por elas mesmas, uma perspectiva pluralista. Já defendi acima as vantagens de se adotar tal perspectiva, estou apenas afirmando que não caberia ao Estado impor tal perspectiva a instituições puramente religiosas.

22 Poder-se-ia dar vários exemplos aqui, mas fiquemos apenas com este para não nos alongarmos ainda mais.

${ }^{23}$ Neste sentido, a proposta aqui exposta, se aproxima de uma ideia de um pluralismo não-constitucional e de uma democracia associativa, defendida, por exemplo por: (BADER, 2003, p. 271).

${ }^{24}$ É muito comum, quando alguém faz este tipo de observação que estou fazendo, ser acusado de estar defendendo que todas as questões deveriam ser decididas no voto e que estou subjugando inclusive a verdade à democracia. Gostaria de deixar muito claro que este não é o caso. Para ilustrar isso gostaria de chamar a atenção para um exemplo típico de controvérsia sobre o ensino do criacionismo nas escolas públicas. Tal ideia é geralmente defendida por literalistas bíblicos que defendem que o criacionismo, idêntico ao relatado na Bíblia, é a explicação correta do mundo e que o Estado não ensinar isso é, no mínimo, uma perspectiva autoritária que não respeita o pluralismo de crenças na sociedade. Do outro lado, temos cientistas, pessoas laicas e até mesmo muitos religiosos não literalistas que afirmam que o estado não deve ensinar o criacionismo nas escolas. Diante desta controvérsia, alguém poderia dizer, vamos votar para ver quem ganha. Ora, uma solução como essa é absurda. Nem tudo num estado democrático deve ser decidido democraticamente. A democracia não elimina outros critérios de resolução de controvérsias. $\mathrm{O}$ aqui relatado é uma típica controvérsia de origem científica e, portanto, deveria ser decidida dentro de critérios científicos. Esse foi, por exemplo, o entendimento da Suprema Corte Americana, em 1982, sobre uma lei do Arkansas de 1981 que determinava que a teoria criacionista deveria ser apresentada nas escolas puramente como uma teoria científica, sem referência a Deus. A suprema corte entendeu, entre outras coisas, que a controvérsia entre criacionistas e evolucionistas não deveria ser resolvida pelo legislativo ou pelos tribunais, mas pela comunidade científica, a qual também tem o poder de definir o status do que é e do que não é científico (BARBOUR, 2004, p. 30). 


\section{Bibliografia}

BADER, V. Religious Diversity and Democratic Institutional Pluralism. In.: Political Theory, v. 31, n. 2. 2003. P. 265-294.

BARBOUR. I. G. Quando a ciência encontra a religião. São Paulo: Cultrix, 2004.

BARTH, K. Church dogmatics. Vol I. Edinburgh: T \& T Clark, 1956.

BERGER, P. L. Os múltiplos altares da modernidade: rumo a um paradigma da religião numa época pluralista. Petrópolis: Vozes, 2017.

CLIFFORD, W. K. A ética da crença. In.: Murcho, D. (Org.). A ética da crença. Lisboa: Bizâncio, 2010.

DAWKINS, R. Deus: um delírio. São Paulo: Companhia das Letras, 2007.

ENGELHARDT, H. T. Fundamentos da Bioética. São Paulo: Loyola, 2008.

HABERMAS, J. Entre naturalismo e religião: estudos filosóficos. Rio de Janeiro: Tempo Brasileiro, 2017.

HARRISON, V. S. Internal Realism and the Problem of Religious Diversity. In.: Philosophia, 34, 2006. pp. 287-301.

HARRISON, V. S. Internal Realism, Religious Pluralism and Ontology. In.: Philosophia, 36. 2008. pp. 97-110.

HARRISON, V. S. Philosophy of religion, fictionalism, and religious diversity. In.: International Journal of Philosophy of Religion, 2010. pp. 43-58.

HARRISON, V. S. An Internal Pluralist Solution to the Problem of Religious and Ethical Diversity. In.: Sophia, 51, 2012. pp. 71-86.

HARRISON, V. S. Seeing the Dao: conceptual metaphors and the philosophy of religion. In.: Religious Studies, V 51, n 3, 2015. pp. 307-322.

HICK, J. God Has Many Names. Philadelphia: The Westminster Press, 1982.

HICK, J. Problems of religious pluralism. New York: St. Martin's, 1985.

HICK, J. An Interpretation of Religion: Humanity's Varied Response to the Transcendent. London: Palgrave Macmillan, 1989.

HICK, J. The Rainbow of Faiths: Critical Dialogues on Religious Pluralism. London: SCM Press, 1995. 
HICK, J. The new Frontier of Religion and Science: Religious Experience, Neuroscience and the Transcendent. Palgrave Macmillan, 2010.

JAMES, W. A vontade de acreditar. In.: Murcho, D. (org.). A ética da crença. Lisboa: Bizâncio, 2010.

LOCKE, J. An Essay concerning human understanding. London: Wordswoth Editions, 2014.

MARITAIN, J. The Degrees of Knowledge. Notre Dame Press, 1959.

MEISTER, C. (ed.). The Oxford Handbook of Religious Diversity. Oxford: Oxford University Press, 2011.

PLANTINGA, A. Conhecimento e crença cristã. Brasília: Academia Monergista, 2016.

- A defense of Religious Exclusivism. In.: Quinn, P. L. and Meeker, K. (Eds). The Philosophical Challenge of Religious diversity, 2000. pp. 172-192.

PLANTINGA, A. \& WOLTERSTORFF, N. Faith and Rationality: reasons and belief in God. Notre Dame: University of Notre Dame Press, 2009.

PUTNAM, H. Reason, truth and history. Cambridge: Cambridge University Press, 1992.

RAHNER, K. Christians and the Non-Christian Religions. In.: Hick, J. \& Hebblethwaite, B. (eds.). Christianity and Other Religions. Oxford: One World, 2001. pp. 19-38.

RAHNER, Curso fundamental da fé. São Paulo: Paulus, 2008.

RUNZO, J. Pluralism and relativism. In.: Meister, C. Oxford Handbook of Religious Diversity. Oxford, Oxford University Press. 2010. pp. 61-76.

SPICA, M.A. Language, Belief and Plurality: a contribution to understanding religious diversity. In.: International Journal for Philosophy of Religion, v 83, n 2, 2018. pp. 169 181

SPICA, M. A. O lugar dos discursos religiosos em uma sociedade plural. In. Martinez, H. L.; Spica, M. A. (org.) Religião em um mundo plural: debates desde a filosofia. Pelotas: Nepfil, 2014. pp. 317-336.

SPICA, M. A. Pluralidade e diálogo inter-religioso: possibilidades e limites das atuais abordagens pluralistas (no prelo).

STENMARK, M. How to relate Science and Religion: A multidimensional model. Michigan: WM. B. Eerdmans Publishing, 2004.

SWINBURNE, R. A existência de Deus. Brasília: Academia Monergista, 2015.

TOURAINE, A. O que é a democracia?. Petrópolis: Vozes, 1996. 
TRIGG, R. Religious diversity: philosophical and political dimensions. New York: Cambridge University Press, 2014.

TWISS, S. B. The Philosophy of Religious Pluralism: a critical appraisal of Hick and his critics. In.: Phillip L. Quinn \& Kevin Meeker (Eds.). The philosophical challenge of religious diversity. New York: Oxford University Press, 1999. pp. 67-98.

WAINWRIGHT, W. Competing Religious Claims. In.: Mann, W. (ed). The Blackwell Guide to the Philosophy of Religion. Oxford: Blackwell, 2005. pp. 220-240

WOLTERSTORFF, N. Understanding Liberal Democracy: essays in Political Philosophy. Edited by Terence Cuneo. Oxford: Oxford University Press, 2012. 